\title{
Urinary Tract Infection Molecular Mechanisms and Clinical Translation
}

\author{
Gabriela Godaly *, Ines Ambite, Manoj Puthia, Aftab Nadeem, James Ho, Karoly Nagy, \\ Yujing Huang, Gustav Rydström and Catharina Svanborg
}

\begin{abstract}
Department of Microbiology, Immunology and Glycobiology (MIG), Institute of Laboratory Medicine, Lund University, 22100 Lund, Sweden; ines.ambite@med.lu.se (I.A.); manoj.puthia@med.lu.se (M.P.); aftab.nadeem@med.lu.se (A.N.); james.hcs@gmail.com (J.H.); dr.nkaroly@gmail.com (K.N.); yujing.huang@med.lu.se (Y.H.); gustav.rydstrom@med.lu.se (G.R.); catharina.svanborg@med.lu.se (C.S.)

* Correspondence: gabriela.godaly@med.lu.se
\end{abstract}

Academic Editor: Lawrence S. Young

Received: 12 November 2015; Accepted: 5 February 2016; Published: 24 February 2016

\begin{abstract}
Rapid developments in infection biology create new and exciting options for individualized diagnostics and therapy. Such new practices are needed to improve patient survival and reduce morbidity. Molecular determinants of host resistance to infection are being characterized, making it possible to identify susceptible individuals and to predict their risk for future morbidity. Immunotherapy is emerging as a new strategy to treat infections worldwide and controlled boosting of the host immune defense represents an important therapeutic alternative to antibiotics. In proof of concept studies, we have demonstrated that this approach is feasible. The long-term goal is not just to remove the pathogens but to also develop technologies that restore resistance to infection in disease-prone patients and devise personalized therapeutic interventions. Here, we discuss some approaches to reaching these goals, in patients with urinary tract infection (UTI). We describe critical host signaling pathways that define symptoms and pathology and the genetic control of innate immune responses that balance protection against tissue damage. For some of these genes, human relevance has been documented in clinical studies, identifying them as potential targets for immune-modulatory therapies, as a complement to antibiotics.
\end{abstract}

Keywords: immunomodulation; genetics; innate immunity; urinary tract infection; susceptibility

\section{Introduction}

Key questions in infection biology have been addressed in the urinary tract and mechanistic insights gained in this model have proven relevant to other infections, as well. Urinary tract infections (UTIs) begin when bacteria gain access to the urinary tract and attack the mucosa in the urinary bladder, ureters and/or the renal pelvis. Symptoms are caused by an excessive host response to infection and an inflammatory tissue infiltrate is the main cause of symptoms and disease. Acute cystitis and acute pyelonephritis can therefore be regarded as infection-driven inflammatory disorders of the bladder and kidneys, respectively. In addition, the urinary tract may host large numbers of bacteria without causing symptoms. In patients with asymptomatic bacteriuria (ABU), bacteria create a symbiotic relationship, which allows for long-term persistence and protects the host against infection with more virulent strains. The challenge is to understand what makes bacteria uropathogens or "commensals" ABU strains, why some patients develop acute pyelonephritis while others develop ABU, and why some individuals are prone to UTI, in the first place. The mission is to use the new molecular tools to counter the burden of disease. Studies from many groups are now bringing us closer to the point of translating into molecular language these conceptual advances and provide suggestions for new therapies and diagnostic markers. 
Our strategy has been to elucidate molecular mechanisms of UTI sequentially, from the initial contact of bacteria to the mucosa to the immune response and genetic susceptibility profiles. Our main goals have been to

1. Identify key, virulence factors that distinguish pathogens from commensals.

2. Characterize critical host signaling pathways that define symptoms and pathology.

3. Inactivate specific genes that control these pathways and characterize the consequences for protection and pathology.

4. Confirm the relevance of these genetic variants for disease in susceptible or resistant patient groups.

5. Address how ABU strains achieve the state of "commensalism".

6. Develop immune-modulatory therapies, as a complement to antibiotics.

This brief review is intended as an introduction to these questions, with some relevant references. The individual papers in this Special Issue of Pathogens, present in greater detail the results from leaders in the field and the resulting advances in understanding of the molecular basis of UTI (Table 1).

Table 1. The individual papers in this Special Issue of Pathogens, present in greater detail the results and the resulting advances in understanding of the molecular basis of UTI.

\begin{tabular}{|c|c|}
\hline Name & Title \\
\hline \multirow[t]{2}{*}{ Bruce Beutler } & $\begin{array}{c}\text { KEY NOTE LECTURE } \\
\text { Pathogens, Commensals, And Immunity: From the } \\
\text { Perspective of The Urinary Bladder }\end{array}$ \\
\hline & HOST SUSCEPTIBILITY TO INFECTION \\
\hline Catharina Svanborg & Urinary Tract Infection Molecular Mechanisms and Clinical Translation \\
\hline David Hains & Genetic Variation in Vesicoureteral Reflux and its Sequelae \\
\hline \multirow[t]{2}{*}{ Christian Kurts, Daniel Engel } & $\begin{array}{l}\text { Neutrophil-Migration into the Infected Uroepithelium is Regulated by } \\
\text { the Crosstalk between Resident and Helper Macrophages }\end{array}$ \\
\hline & HOST RESPONSE MODULATION BY BACTERIA \\
\hline Soman Abraham & Why Serological Responses During Cystitis are Limited \\
\hline Thomas Miethke & $\begin{array}{l}\text { A comparative analysis of the mechanism of Toll-like } \\
\text { receptor-disruption by TIR-containing protein C } \\
\text { from uropathogenic Escherichia coli }\end{array}$ \\
\hline Ines Ambite & Bacterial control of host gene expression through RNA polymerase II * \\
\hline \multirow[t]{2}{*}{ David Hunstad } & $\begin{array}{l}\text { Subversion of host innate immunity by uropathogenic } \\
\text { Escherichia coli binocular }\end{array}$ \\
\hline & ASYMPTOMATIC BACTERIAL CARRIAGE \\
\hline Lindsay Nicolle & The Paradigm Shift to Nontreatment of Asymptomatic Bacteriuria * \\
\hline Björn Wullt & $\begin{array}{l}\text { Asymtomatic Bacteriuria as a Model to Study the Coevolution of } \\
\text { Hosts and Bacteria }\end{array}$ \\
\hline \multirow[t]{2}{*}{ Tommaso Cai } & $\begin{array}{l}\text { Asymptomatic bacteriuria in clinical urological practice: antibiotic } \\
\text { preoperative prophylaxis and treatment of recurrent UTI }\end{array}$ \\
\hline & BACTERIAL VIRULENCE \\
\hline Harry Mobley & $\begin{array}{c}\text { Measuring E. coli Gene Expression During Human Urinary } \\
\text { Tract Infections }\end{array}$ \\
\hline Matthew Mulvey & $\begin{array}{l}\text { Histone Deacetylase } 6 \text { Regulates Bladder Architecture and Host } \\
\text { Susceptibility to Uropathogenic Escherichia coli }\end{array}$ \\
\hline Swaine Chen & $\begin{array}{l}\text { Application and optimization of relE as a negative selection marker } \\
\text { for making definitive genetic constructs in uropathogenic } \\
\text { Escherichia coli strain UTI89 }\end{array}$ \\
\hline
\end{tabular}


Table 1. Cont.

\begin{tabular}{cr}
\hline Name & Title \\
\hline Swaine Chen & $\begin{array}{c}\text { Brighter fluorescent derivatives of UTI89 utilizing a monomeric vGFP } \\
\text { Eric Klein }\end{array}$ \\
\hline Perspective: Adhesion mediated signal transduction in \\
uropathogenic E. coli
\end{tabular}

\section{Key, Virulence Factors that Distinguish Pathogens from Commensals}

The virulence concept in UTI emerged when it was recognized that specific properties distinguish Escherichia coli (E. coli) strains that cause severe disease from strains that are carried asymptomatically, in the urinary tract [2]. These "virulence factors" were initially defined epidemiologically, by disease association. Increasingly, it was recognized that virulence reflected direct effects of certain strains on host tissues, and mechanisms for tissue attack began to be analyzed in cellular models. The adhesion of virulent $E$. coli strains provided an early example of pathogen crosstalk with infected host tissues, opening up the field of "cellular microbiology". Subsequently, P fimbriae were identified as key virulence-enhancing ligands, also useful as markers of virulent strains that cause urosepsis [3-6].

In parallel with the discoveries of bacterial adhesion, methods were developed to identify and classify strains that cause different forms of UTI and to distinguish the disease isolates from commensal strains in the fecal flora. Interestingly, the molecules chosen for classification were often virulence factors in their own right, acting as endotoxins (LPS, O antigens), bacterial survival enhancers (Capsular polysaccharides, $\mathrm{K}$ antigens) and organelles for bacterial motility (flagella, $\mathrm{F}$ antigens). The toxin hemolysin was also identified as an early marker of uropathogenic strains, compared to isolates from the fecal flora, as well as aerobactin, one of the first iron-binding proteins to be identified in UPEC [7]. Based on surface antigens or multilocus isoenzyme typing, bacterial lineages or clones were characterized and essential aspects of the population dynamics of UPEC were revealed, including the horizontal transfer of genes involved in adhesion and bacterial adaptation to the urinary tract environment [8,9]. The definition of pathogenic clones and their virulence factors was given a molecular context by the pathogenicity island concept [10], which demonstrated that genes encoding virulence factors in uropathogens were clustered and flanked by insertion elements, indicating that they might have moved, "en bloc", into the chromosome of ancestral E. coli strains and become fixed by the selective advantage afforded by these genes in the infected host [11]. 
Virulence factors are distinct from the bacterial determinants of persistence, as they are engaged in tissue attack and disease. ABU strains colonize the human urinary tract for extended periods of time and create a state of symbiosis with the host. In epidemiological surveys, about $50 \%$ of $A B U$ strains are related to the virulent clones but fail to express virulence factors, due to mutations or deletions that attenuate virulence (see Dobrindt et al., this Special Issue [1]). In addition, ABU strains modify the host environment in their favor by suppressing host gene expression. A reduction in RNA Polymerase II dependent gene expression by $>60 \%$ was detected already $24 \mathrm{~h}$ after bacteria entered the human urinary tract. This included genes that regulate the immune status illustrating how "non-virulent" strains bacteria can tame the antibacterial host defense (see Ambite et al., this Special Issue [1]). These findings change our view on asymptomatic carrier strains from passive bystanders to active participants in host-microbial co-evolution.

For comprehensive updates on bacterial virulence factors and UTI, please see Mobley et al. [12] and Hultgren et al. [13]. See also Hunstad et al., Hultgren et al., Klein et al., and Pichl et al., and Mobley et al., this Special Issue [1].

\section{Critical Signaling Pathways that Define Symptoms and Pathology}

The strong association between adherence, virulence and disease severity, indicated that there must be a direct molecular link between the bacteria, their epithelial cell receptors and disease. We provided such a molecular link, by showing that infected epithelial cells produce inflammatory mediators that start the mucosal inflammatory response $[14,15]$. Surrounding cells and recruited inflammatory cells then take the decisions about the quality and quantity of the mucosal response, leading to disease or protection [16]. The epithelial cells are thus important players in the mucosal immune system; acting both as docking sites for the bacteria and as sensors of microbial attack [17].

The quality of the inflammatory response varies with the virulence repertoire of the infecting strain. It is also determined by the expression of specific host cell receptors and by the signaling pathways that they activate $[18,19]$. For example, the binding of $P$ fimbriae to glycolipid receptors alerts the host to the presence of virulent bacteria and activates an innate immune response in the urinary tract mucosa [19]. Through sequential activation of TLR4 and the TRIF/TRAM adaptors, this signaling pathway engages MAPKs, p38 and CREB leading to the formation of transcription factor complexes defined by IRF3 and the activation of type I IFN responses. In parallel, phosphorylated FOS and JUN form the AP1 transcription factor complex, which activates chemokine and cytokine production.

Fimbriae-receptor interactions illustrate how signaling pathways in the host are controlled by virulence factors and their receptors. A change from P- to Type 1 fimbrial expression shifts the host response to the MyD88 and TIRAP dependent arm of the TLR4 signaling pathway, leading to NFkB dependent transcription and inflammasome activation [20]. For comprehensive updates on the innate immune response to UTI, please see Godaly et al. [16] and Ambite et al. [17].

\section{Inactivate Specific Genes that Control These Pathways and Characterize the Consequences for Protection and Pathology}

Inflammation and disease is essentially a product of a failed innate immune response (Figure 1). The importance of innate immunity for host resistance against UTI was first discovered in the early 1980s in the murine UTI model [21]. We found that C3H/HeJ mice had increased UTI susceptibility, defined by delayed bacterial clearance and impaired inflammation. As a result, $\mathrm{C} 3 \mathrm{H} / \mathrm{HeJ}$ mice remained chronically infected, without evidence of tissue damage. The "Lps" gene defect in C3H/HeJ mice was subsequently identified by Beutler et al. [22] and the importance of Tlr4 for host resistance to infection has since been confirmed in numerous models [19,23-28]. 


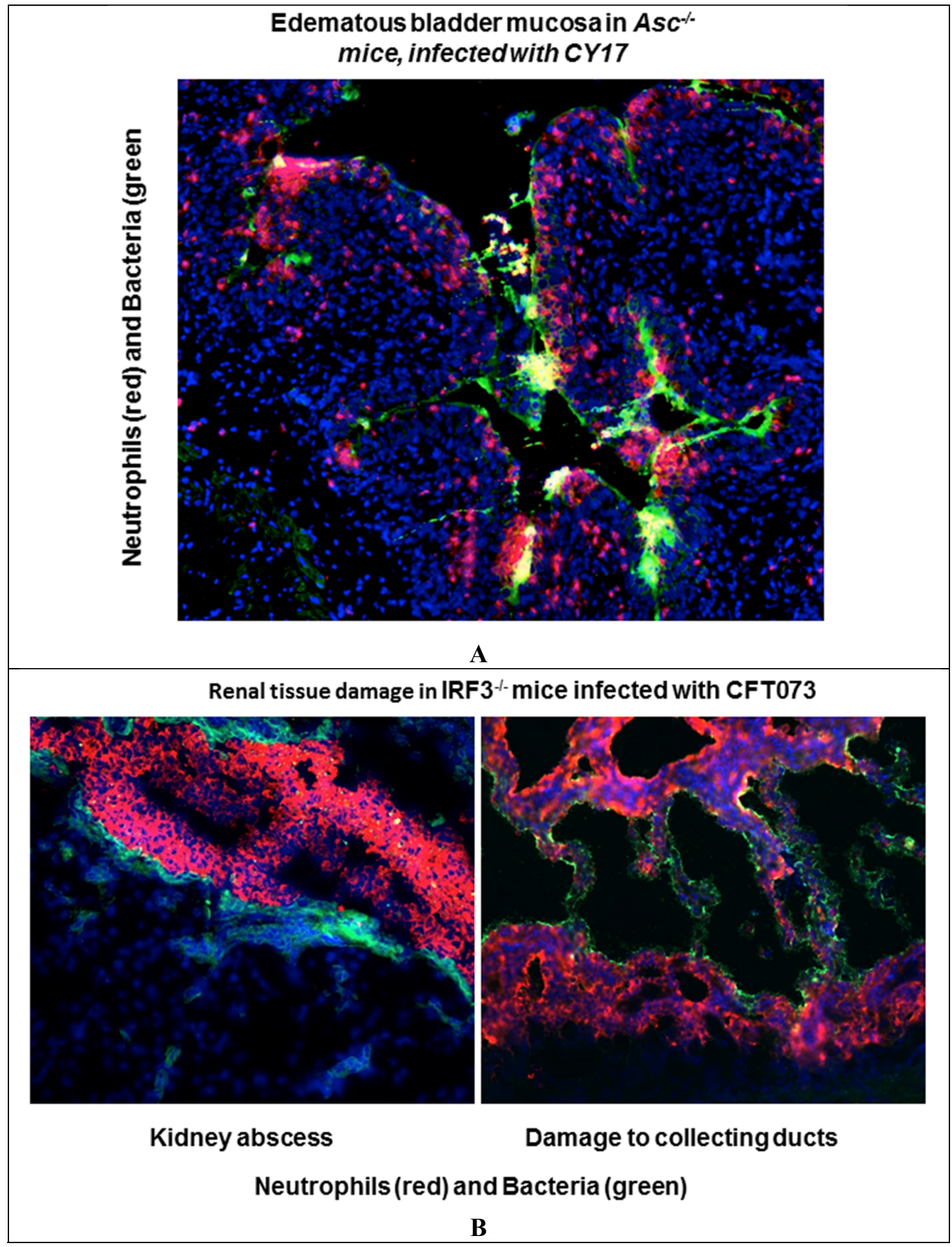

Figure 1. Inflammatory infiltrates in bladder and kidney tissue sections from infected mice with genetic deficiencies that enhance susceptibility to infection. Staining with specific antibodies to neutrophils (red) or E. coli (green). Nuclei are counterstained with DAPI. (A) Edematous bladder mucosa in $A s^{-1-}$ mice infected with the acute cystitis strain E. coli CY-17; (B) Renal tissue destruction in Irf3-/- mice' after infection with the acute pyelonephritis strain E. coli CFR073.

The observation in $\mathrm{C} 3 \mathrm{H} / \mathrm{HeJ}$ mice was conceptually important, as it demonstrated that the susceptibility to UTI is controlled by the host inflammatory response-later named "innate immunity" [23]. It also showed that UTI susceptibility is determined by the function of specific 
genes that control this innate immune response. A number of genetic defects have since been shown to influence UTI susceptibility in animal models and clinical studies (reviewed in [29]). For example, $\mathrm{mCxcr} 2^{-/-}$mice with a neutrophil migration- and activation deficiency, develop severe APN with urosepsis followed by abscess formation and renal scaring [30-32]. Irf3 ${ }^{-/}$mice develop a similar phenotype with over-activation of the innate immune response, severe, acute disease with urosepsis and abscess formation within one week of infection [19]. Mutant mice lacking Tlr5, Tlr11, Thp and cytochrome c oxidase subunit II (Cox2) are also more susceptible to UTI than mice with the wild-type genotype.

The strong effects of single genes were unexpected and controversial, as UTI susceptibility was thought at the time to be too complex to be controlled by single genes (reviewed in [29]).

Many of the identified genes influence the function of neutrophils, which are crucial effectors of the antibacterial defense in the urinary tract. Neutrophils are rapidly recruited by the chemotactic gradient emerging from the infected urothelium. Infection activates a broad chemokine response to infection, including CXC (CXCL1, CXCL5, CXCL8, CXCL9, and CXCL10) and CC chemokines (CCL2, CCL3, and CCL5) [33,34]. The main neutrophil chemoattractant is CXCL8 chemokine family, which guides neutrophil migration into the mucosa and the exit across the mucosa into the urine, which is a prerequisite to maintain tissue homeostasis [35,36]. Furthermore, activated neutrophils provide signals for the activation and maturation of macrophages and other mucosal cells, such as mast cells (see Abraham et al., this Special Issue [1]). TNF-mediated crosstalk between neutrophils and macrophages has been shown to optimize the antibacterial defense in the urinary tract (see Zec et al., this Special Issue [1]).

\section{Relevance of Genetic Variants for Disease in Susceptible or Resistant Patient Groups}

Genes that control UTI susceptibility in mice are also polymorphic in UTI prone patients [29]. Inheritance of UTI susceptibility was confirmed in a three-generation family study, with low CXCR1 expression in the susceptible cases in those families. In contrast to classical human immunodeficiencies, the identified UTI susceptibility determinants do not primarily affect structural genes, but alter regulators of transcriptional efficiency.

For example, ABU patients carry TLR4 promoter genotype variants that lower TLR4 expression [37]. Intronic and 3'UTR variants in patients with acute pyelonephritis reduce CXCR1 transcription efficiency or RNA stability, permitting the infected host to regulate responses to a family of CXC chemokines that converge on this receptor [38]. In addition, we have identified promoter sequence variants that reduce the expression of Irf3, a key transcription factor that controls the TLR4-dependent response to uropathogenic bacteria. Transcriptional regulation provides a mechanism of genetic regulation different from the rare monogenetic disorders that affect innate immunity. In addition to the rare, complete loss of structural gene function, evolution appears to favor changes in the genetic make up, with less dramatic consequences for infected hosts $[20,37,38]$.

\section{Address how ABU Strains Achieve the State of "Commensalism"}

For articles addressing this point, please see Dobrindt et al., Ambite et al. and Wullt et al. in this Special Issue [1].

\section{Immunomodulatory Therapies as a Complement to Antibiotics}

As illustrated above, innate immunity provides an immediate defense against UTI. In resistant individuals, specific recognition and activation strategies eliminate pathogens while sustaining symbiosis with commensals. As the innate immune response relies on inflammatory pathways to execute defense functions, the activation of innate immune defenses has negative consequences, including destruction of host tissues. This lack of specificity and the genetic defects that upset the response, contribute to the pathobiology of disease. 
The two-faced nature of innate immunity complicates the development of immune-modulatory therapies. An important challenge is to identify molecular targets that can be exploited to attenuate destructive inflammatory responses while accentuating those that are protective. The intervention needs to be precise, so that symptoms and tissue destruction caused by exaggerated host responses can be isolated and avoided.

We have identified two novel targets for immuno-modulatory therapies in UTI:

1. siRNA interference to attenuate the exaggerated inflammatory response in Irf3 ${ }^{-/-}$mice with severe acute pyelonephritis.

2. Inhibitors of IL-1 and IL-1 processors, to attenuate the IL-1-dependent hyper-inflammatory state in acute cystitis.

Therapeutic efficacy has been demonstrated in the murine UTI model with promising results for translation into the clinic. To clarify, the term immunomodulation means that the immune system is specifically modified by interference with molecular regulators of the immune response, not by molecules with a more general mechanism of action, such as hormones, vitamins or food stuffs that cause numerous and complex changes in the host.

In addition, preventive approaches are being explored, such as the development of vaccines against iron-binding proteins (Mobley et al. this Special Issue) or small molecule inhibitors of type 1 fimbrial binding to host cells (Hultgren et al., this Special Issue).

\section{Conclusions}

Despite their prevalence and serious consequences for patients and society, UTIs are often not handled optimally. Ironically, the pace of change may be increased by the rapid emergence of antibiotic resistance in uropathogenic bacteria. The patients need alternative therapeutic approaches, in order to avoid a return to UTI-associated mortality, end stage renal disease and abortions or premature delivery. The increasingly problematic question is-how do we treat UTI and who do we treat with what?

Provided that the molecular findings discussed in this Special Issue are used, it will be possible to diagnose UTI susceptibility with better accuracy and to devise new therapeutic tools (Connolly et al. and Chao et al. in this Special Issue). For example, important diagnostic questions can be addressed with better accuracy. Bacterial virulence typing may be used to determine if fever in a patient with bacteriuria is evidence of acute pyelonephritis or ABU with fever of other origin. Infants and children with the first episode of acute pyelonephritis can potentially be identified, using genetic and proteomic tools. Genetic and proteomic screens may also be used to reduce the need for invasive imaging procedures and to increase predictive accuracy. Another relevant clinical question is the risk for postoperative infections in patients undergoing urogenital surgery.

Immunomodulatory therapy has great potential, especially if it will be possible to identify therapeutic targets that selectively attenuate "bad inflammation" and control destructive innate immune responses in kidneys and bladders. The development of specific inhibitors of "bad inflammation" will be essential, as well as clinical studies, to validate their function in relevant animal models.

Acknowledgments: We gratefully acknowledge the support of the Swedish Medical Research Council; Medical Faculty (Lund University); Swedish Cancer Society; the Sharon D Lund, Söderberg and Österlund Foundations; the Anna-Lisa and Sven-Erik Lundgren-, Maggie Stephens-, Inga-Britt and Arne Lundberg- and HJ Forssman Foundations; the Royal Physiographic Society; and the Network of Excellence: EuroPathoGenomics.

Author Contributions: C.S., G.G., I.A., M.P., A.N., J.H., K.N., Y.H., and G.R. contributed to the writing of the manuscript.

Conflicts of Interest: The authors declare no conflict of interest. 


\section{References}

1. The Special Issue "Molecular Aspects of Urinary Tract Infection". Available online: http://www.mdpi.com/ journal/pathogens/special_issues/urinary-tract-infection (accessed on 23 February 2016).

2. Eden, C.S.; Hanson, L.A.; Jodal, U.; Lindberg, U.; Akerlund, A.S. Variable adherence to normal human urinary-tract epithelial cells of Escherichia coli strains associated with various forms of urinary-tract infection. Lancet 1976, 1, 490-492. [PubMed]

3. Lomberg, H.; Eden, C.S. Influence of p blood group phenotype on susceptibility to urinary tract infection. FEMS Microbiol. Immunol. 1989, 1, 363-370. [CrossRef] [PubMed]

4. Johnson, J.R. Virulence factors in Escherichia coli urinary tract infection. Clin. Microbiol. Rev. 1991, 4, 80-128. [PubMed]

5. Svensson, M.; Platt, F.M.; Svanborg, C. Glycolipid receptor depletion as an approach to specific antimicrobial therapy. FEMS Microbiol. Lett. 2006, 258, 1-8. [CrossRef] [PubMed]

6. Bergsten, G.; Samuelsson, M.; Wullt, B.; Leijonhufvud, I.; Fischer, H.; Svanborg, C. Papg-dependent adherence breaks mucosal inertia and triggers the innate host response. J. Infect. Dis. 2004, 189, 1734-1742. [CrossRef] [PubMed]

7. Orskov, I.; Svanborg Eden, C.; Orskov, F. Aerobactin production of serotyped Escherichia coli from urinary tract infections. Med. Microbiol. Immunol. 1988, 177, 9-14. [PubMed]

8. Caugant, D.A.; Levin, B.R.; Orskov, I.; Orskov, F.; Svanborg Eden, C.; Selander, R.K. Genetic diversity in relation to serotype in Escherichia coli. Infect. Immun. 1985, 49, 407-413. [PubMed]

9. Plos, K.; Hull, S.I.; Hull, R.A.; Levin, B.R.; Orskov, I.; Orskov, F.; Svanborg-Eden, C. Distribution of the p-associated-pilus (pap) region among Escherichia coli from natural sources: Evidence for horizontal gene transfer. Infect. Immun. 1989, 57, 1604-1611. [PubMed]

10. Dobrindt, U.; Hochhut, B.; Hentschel, U.; Hacker, J. Genomic islands in pathogenic and environmental microorganisms. Nat. Rev. Microbiol. 2004, 2, 414-424. [CrossRef] [PubMed]

11. Caugant, D.A.; Levin, B.R.; Selander, R.K. Genetic diversity and temporal variation in the E. coli population of a human host. Genetics 1981, 98, 467-490. [PubMed]

12. Nielubowicz, G.R.; Mobley, H.L. Host-pathogen interactions in urinary tract infection. Nat. Rev. Urol. 2010, 7 , 430-441. [CrossRef] [PubMed]

13. Flores-Mireles, A.L.; Walker, J.N.; Caparon, M.; Hultgren, S.J. Urinary tract infections: Epidemiology, mechanisms of infection and treatment options. Nat. Rev. Microbiol. 2015, 13, 269-284. [CrossRef] [PubMed]

14. De Man, P.; van Kooten, C.; Aarden, L.; Engberg, I.; Linder, H.; Svanborg Eden, C. Interleukin-6 induced at mucosal surfaces by gram-negative bacterial infection. Infect. Immun. 1989, 57, 3383-3388. [PubMed]

15. Agace, W.; Hedges, S.; Andersson, U.; Andersson, J.; Ceska, M.; Svanborg, C. Selective cytokine production by epithelial cells following exposure to Escherichia coli. Infect. Immun. 1993, 61, 602-609. [PubMed]

16. Godaly, G.; Ambite, I.; Svanborg, C. Innate immunity and genetic determinants of urinary tract infection susceptibility. Curr. Opin. Infect. Dis. 2015, 28, 88-96. [CrossRef] [PubMed]

17. Ambite, I.; Lutay, N.; Godaly, G.; Svanborg, C. Urinary tract infections and the mucosal immune system. In Mucosal Immunology, 4th ed.; Jiri Mestecky, W.S., Russell, M.W., Cheroutre, H., Lambrecht, B.N., Kelsall, B.L., Eds.; Academic Press: Boston, MA, USA, 2015; pp. 2039-2058.

18. Hedlund, M.; Wachtler, C.; Johansson, E.; Hang, L.; Somerville, J.E.; Darveau, R.P.; Svanborg, C. $\mathrm{P}$ fimbriae-dependent, lipopolysaccharide-independent activation of epithelial cytokine responses. Mol. Microbiol. 1999, 33, 693-703. [CrossRef] [PubMed]

19. Fischer, H.; Lutay, N.; Ragnarsdottir, B.; Yadav, M.; Jonsson, K.; Urbano, A.; Al Hadad, A.; Ramisch, S.; Storm, P.; Dobrindt, U.; et al. Pathogen specific, irf3-dependent signaling and innate resistance to human kidney infection. PLoS Pathog. 2010, 6, e1001109. [CrossRef] [PubMed]

20. Fischer, H.; Yamamoto, M.; Akira, S.; Beutler, B.; Svanborg, C. Mechanism of pathogen-specific tlr4 activation in the mucosa: Fimbriae, recognition receptors and adaptor protein selection. Eur. J. Immunol. 2006, 36, 267-277. [CrossRef] [PubMed]

21. Hagberg, L.; Hull, R.; Hull, S.; McGhee, J.R.; Michalek, S.M.; Svanborg Eden, C. Difference in susceptibility to gram-negative urinary tract infection between $\mathrm{c} 3 \mathrm{~h} / \mathrm{h}$ ej and $\mathrm{c} 3 \mathrm{~h} / \mathrm{hen}$ mice. Infect. Immun. 1984, 46, 839-844. [PubMed] 
22. Poltorak, A.; He, X.; Smirnova, I.; Liu, M.Y.; Van Huffel, C.; Du, X.; Birdwell, D.; Alejos, E.; Silva, M.; Galanos, C.; et al. Defective lps signaling in $\mathrm{c} 3 \mathrm{~h} / \mathrm{hej}$ and c57bl/10sccr mice: Mutations in tlr4 gene. Science 1998, 282, 2085-2088. [CrossRef] [PubMed]

23. Hagberg, L.; Briles, D.E.; Svanborg-Eden, C. Evidence for separate genetic defects in c3h/hej and c3heb/fej mice, that affect susceptibility to gram-negative infections. J. Immunol. 1985, 134, 4118-4122. [PubMed]

24. Shahin, R.D.; Engberg, I.; Hagberg, L.; Svanborg Eden, C. Neutrophil recruitment and bacterial clearance correlated with lps responsiveness in local gram-negative infection. J. Immunol. 1987, 138, 3475-3480. [PubMed]

25. Hopkins, W.J.; Gendron-Fitzpatrick, A.; Balish, E.; Uehling, D.T. Time course and host responses to Escherichia coli urinary tract infection in genetically distinct mouse strains. Infect. Immun. 1998, 66, 2798-2802. [PubMed]

26. Frendeus, B.; Wachtler, C.; Hedlund, M.; Fischer, H.; Samuelsson, P.; Svensson, M.; Svanborg, C. Escherichia coli p fimbriae utilize the toll-like receptor 4 pathway for cell activation. Mol. Microbiol. 2001, 40, 37-51. [CrossRef] [PubMed]

27. Hedlund, M.; Frendeus, B.; Wachtler, C.; Hang, L.; Fischer, H.; Svanborg, C. Type 1 fimbriae deliver an lpsand tlr4-dependent activation signal to cd14-negative cells. Mol. Microbiol. 2001, 39, 542-552. [CrossRef] [PubMed]

28. Schilling, J.D.; Martin, S.M.; Hung, C.S.; Lorenz, R.G.; Hultgren, S.J. Toll-like receptor 4 on stromal and hematopoietic cells mediates innate resistance to uropathogenic Escherichia coli. Proc. Natl. Acad. Sci. USA 2003, 100, 4203-4208. [CrossRef] [PubMed]

29. Ragnarsdottir, B.; Lutay, N.; Gronberg-Hernandez, J.; Koves, B.; Svanborg, C. Genetics of innate immunity and uti susceptibility. Nat. Rev. Urol. 2011, 8, 449-468. [CrossRef] [PubMed]

30. Frendeus, B.; Godaly, G.; Hang, L.; Karpman, D.; Lundstedt, A.C.; Svanborg, C. Interleukin 8 receptor deficiency confers susceptibility to acute experimental pyelonephritis and may have a human counterpart. J. Exp. Med. 2000, 192, 881-890. [CrossRef] [PubMed]

31. Hang, L.; Frendeus, B.; Godaly, G.; Svanborg, C. Interleukin-8 receptor knockout mice have subepithelial neutrophil entrapment and renal scarring following acute pyelonephritis. J. Infect. Dis. 2000, 182, 1738-1748. [CrossRef] [PubMed]

32. Svensson, M.; Irjala, H.; Alm, P.; Holmqvist, B.; Lundstedt, A.C.; Svanborg, C. Natural history of renal scarring in susceptible mil-8rh-/- mice. Kidney Int. 2005, 67, 103-110. [CrossRef] [PubMed]

33. Otto, G.; Braconier, J.; Andreasson, A.; Svanborg, C. Interleukin-6 and disease severity in patients with bacteremic and nonbacteremic febrile urinary tract infection. J. Infect. Dis. 1999, 179, 172-179. [CrossRef] [PubMed]

34. Godaly, G.; Otto, G.; Burdick, M.D.; Strieter, R.M.; Svanborg, C. Fimbrial lectins influence the chemokine repertoire in the urinary tract mucosa. Kidney Int. 2007, 71, 778-786. [CrossRef] [PubMed]

35. Agace, W.W.; Hedges, S.R.; Ceska, M.; Svanborg, C. Interleukin-8 and the neutrophil response to mucosal gram-negative infection. J. Clin. Investig. 1993, 92, 780-785. [CrossRef] [PubMed]

36. Wullt, B.; Bergsten, G.; Fischer, H.; Godaly, G.; Karpman, D.; Leijonhufvud, I.; Lundstedt, A.C.; Samuelsson, P.; Samuelsson, M.; Svensson, M.L.; et al. The host response to urinary tract infection. Infect. Dis. Clin. N. Am. 2003, 17, 279-301. [CrossRef]

37. Ragnarsdottir, B.; Jonsson, K.; Urbano, A.; Gronberg-Hernandez, J.; Lutay, N.; Tammi, M.; Gustafsson, M.; Lundstedt, A.C.; Leijonhufvud, I.; Karpman, D.; et al. Toll-like receptor 4 promoter polymorphisms: Common tlr4 variants may protect against severe urinary tract infection. PLoS ONE 2010, 5, e10734. [CrossRef] [PubMed]

38. Lundstedt, A.C.; McCarthy, S.; Gustafsson, M.C.; Godaly, G.; Jodal, U.; Karpman, D.; Leijonhufvud, I.; Linden, C.; Martinell, J.; Ragnarsdottir, B.; et al. A genetic basis of susceptibility to acute pyelonephritis. PLoS ONE 2007, 2, e825. [CrossRef] [PubMed]

(c) 2016 by the authors; licensee MDPI, Basel, Switzerland. This article is an open access article distributed under the terms and conditions of the Creative Commons by Attribution (CC-BY) license (http://creativecommons.org/licenses/by/4.0/). 